\title{
Syncope és betegmonitorozás
}

\author{
Tomcsányi János
}

\author{
Betegápoló Irgalmasrend Budai Irgalmasrendi Kórháza, Kardiológia, Budapest \\ Levelezési cím: \\ Dr. Tomcsányi János, Budai Irgalmasrendi Kórház, 1027 Budapest, Árpád fejedelem u. 7. \\ E-mail: tomcsanyij@gmail.com
}

\begin{abstract}
A syncope diagnosztikája gyakran komoly diagnosztikai kihívást jelent. A jelen összefoglaló az EKG-monitorozás formáit és a stratégiai lehetőségeket tárgyalja az ajánlások alapján.
\end{abstract}

Kulcsszavak: syncope, monitorozás, Holter-monitor, loop rekorder

\section{Syncope and cardiac monitoring}

The cause of syncope is often a diagnostic challenge. The article provides a comprehensive review of cardiac monitoring modalities and discuss strategies on how to reach the elusive diagnosis based current recommendations.

Keywords: syncope, cardiac monitoring, Holter monitoring, loop recorder

\section{Syncope}

A syncope egy olyan klinikai tünet, ahol az etiológia és a diagnózison alapuló kezelés egy igen szerteágazó, komplex feladat. Ez a közlemény csak az EKG-monitorozásra fókuszál.

Syncopés betegek monitorozásánál három alapkérdés van:

- Kinél indokolt az EKG-monitorozás?

- Milyen monitorozási technikát válasszunk?

- Hogyan értékeljük a rögzített ritmuszavart a syncope szempontjából?

\section{Kinél indokolt az EKG-monitorozás?}

A ritmuszavar monitorozása annál indokolt, akinél nem ismert a syncope etiológiája és a beteg anamnézise és státusza (elsősorban kardiovaszkuláris) alapján a ritmuszavar valószínűsíthető. Fontos, hogy a magas kardiovaszkuláris rizikójú betegeket elkülönítsük a többi betegtől. A legújabb ajánlás három fő csoportot különít el, akinél mindenképpen a kórházi kivizsgálás javasolt a syncope tünetének jelentkezése után (1):

I. Súlyos strukturális szívbetegség (akut iszkémia, akut szívelégtelenség, súlyos aorta-stenosis, pulmonalis embólia, HCM, súlyos mübillentyü-diszfunkció, aorta-disszekció).
II. Súlyos, dokumentált ritmuszavar (kamrai tachycardia, Mobitz II vagy súlyosabb AV-vezetési zavar, pacemaker/ICD-diszfunkció, szimptómás sinus bradycardia vagy pauza, ami nem neurokardiogén eredetűnek tủnik, csatornabetegségek EKG-jelei, amik malignus ritmuszavarra hajlamosítanak).

III. Nem kardiogén, súlyos klinikai állapot (súlyos anémia/GI-vérzés, syncope miatti maior trauma, perzisztáló kóros vitális jelek).

Nem lehet elégszer hangsúlyozni, hogy mennyire fontos a syncope körülményeinek pontos felderítése a mechanizmus megismerése szempontjából.

Ha tehát a syncope ismeretlen eredetű, rekurrál, a beteg pedig nem magas rizikójú és klinikum alapján aritmia eredet feltételezhetö, akkor ambulanter EKG-monitorozás szükséges, amit az ajánlások IB-szinttel jelölnek.

Milyen monitorozási technikát válasszunk? A választ viszonylag könnyű megadni. Értékarányosan olyan módszert kell választani, ahol magas a várható diagnosztikus találat aránya. Az 1 . táblázat azt mutatja be, hogy napjainkban milyen EKG-monitorozási technikák vannak és azok kiknél javasoltak és milyen előnyei és hátrányai vannak az adott monitorozásnak. 
1. TÁBLÁZAT. Különböző monitorozási technikák előnyei, hátrányai

\begin{tabular}{|l|l|l|l|c|}
\hline Módszer & Elöny & Limitáció & Indikáció & DG valószínüsége \\
\hline HOLTER & $\begin{array}{l}\text { Alacsony ár, folyamatos } \\
\text { monitorozás }\end{array}$ & Rövid időintervallum & $\begin{array}{l}\text { Gyakori tünetek } \\
\leq 1 \text { hét }\end{array}$ & $6-22 \%$ \\
\hline $\begin{array}{l}\text { Transztelefonos } \\
\text { monitor }\end{array}$ & Alacsony ár & $\begin{array}{l}\text { Rossz minőség, betegaktiválás, } \\
\text { rövid aritmiát nem detektálhat }\end{array}$ & $\leq 4$ hét & $23-42 \%$ \\
\hline $\begin{array}{l}\text { Külső loop } \\
\text { rekorder }\end{array}$ & $\begin{array}{l}\text { Restrospektív EKG-t is rög- } \\
\text { zít, aszimptómás aritmiát is }\end{array}$ & $\begin{array}{l}\text { Rossz minőség, állandó } \\
\text { viselés, rossz compliance }\end{array}$ & $\leq 4$ hét & $24-47 \%$ \\
\hline $\begin{array}{l}\text { Mobil ambuláns } \\
\text { telemetria }\end{array}$ & $\begin{array}{l}\text { Folyamatos monitorozás, } \\
\text { beteg tünetvezérelte }\end{array}$ & $\begin{array}{l}\text { Folyamatos viselés, rossz } \\
\text { compliance, ár, hozzáférés }\end{array}$ & $\leq 4$ hét & $41-61 \%$ \\
\hline $\begin{array}{l}\text { Implantábilis loop } \\
\text { rekorder }\end{array}$ & $\begin{array}{l}\text { Hosszú monitorozás külső } \\
\text { elektróda nélkül }\end{array}$ & Invazív beavatkozás, ár & $\begin{array}{l}\text { Rekurrens, ismeret- } \\
\text { len syncope, } \geq 4 \text { hét }\end{array}$ & $43-78 \%$ \\
\hline \multicolumn{2}{|l|}{ Europace 2005; 7 (1) 19-24. 2005; 7 (3) 273-279. } & & &
\end{tabular}

Leegyszerüsítve a legjobb eredményt adó vizsgálat az implantábilis loop rekorder (ILR), de az ára és invazív beavatkozás miatt korlátozott azoknak a köre, akiknél javasolt. Természetesen nagyon relatív az, hogy drága. Hiszen az igazán drága az a vizsgálat, ami úgy drága, hogy alacsony a diagnosztikus effektivitása. Amikor az árról beszélünk, akkor nemcsak azt kell figyelembe venni, hogy mennyibe kerül a vizsgálat, hanem azt is, hogy egy korai vizsgálattal és azt követő adekvát kezeléssel hány traumás sérülés, hospitalizáció előzhető meg.

A Picture-vizsgálatban például átlagosan 13 inkonkluzív vizsgálatot végeztek diagnosztikus céllal az ILR-beültetés elött és átlagosan 3 szakember látta a beteget, ahol aztán a beültetett esetekben $78 \%$-os volt a készülék diagnosztikus találata és a diagnosztikus esetek $75 \%$-ában volt az etiológia kardiológiai (2).

Saját adataink retrospektív analízise $69 \%$-os diagnosztikus eredményességet mutatott 52 beteg ILR-monito-

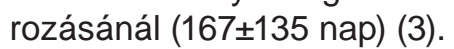

Az európai átlagos ILR-beültetés 80-120/millió lakos, míg itthon 2015-ben is csak 17/millió lakos volt $(3,4)$.

Azonban az európai gyakorlatban is az egyes centru- mok között igen nagy a különbség. A centrumok harmadában $20 \%$ alatt használnak ILR-t rekurrens syncope esetén (4).

\section{Hogyan értékeljük a rögzített ritmuszavart a syncope szempontjából?}

Az egyes klinikailag fontos aritmiafajtákat és azok szerepét a 2. táblázat mutatja (5). Ennek kapcsán bemutatásra kerül néhány jellegzetes ritmuszavar a különböző monitorozási technikákkal.

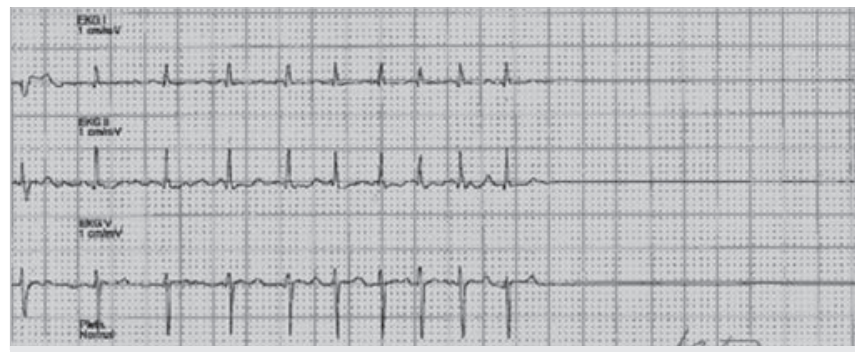

1. ÁBRA. Telemetriás monitorozás paroxizmális pitvarfibrillációt és annak megszűnte után 4 szekundumos pauzát igazolt a syncopék hátterében

\section{TÁBLÁZAT. Ritmuszavarok klasszifikációja és értékelése}

\begin{tabular}{|l|l|l|l|l|}
\hline Klasszifikáció & Sinuscsomó & AV-csomó & EKG mech. & Syncope mech. \\
\hline \begin{tabular}{l} 
Asystole $(\mathbf{3} \mathbf{~ s )}$ \\
\hline 1.
\end{tabular} & Sinus arrest & Normál & $\begin{array}{l}\text { Hirtelen sinus arest v. progresz- } \\
\text { Szív lassulás }\end{array}$ & Vazovagalis \\
\hline 2. & Bradycardia & AV-blokk & AV-blokk és sinus bradycardia & Vazovagalis \\
\hline 3. & Normál & AV-blokk & Paroxizmális AV-blokk & AV-csomó betegség \\
\hline Bradycardia & & & & \\
\hline 1. & $>30 \%$ csökkenés & Normál & & Vazovagális \\
\hline 2. & Sinus $<40 / m i n$ & Normál & & Vazovagális \\
\hline Tachycardia & & & & \\
\hline 1. & Progresszív & Normál & Sinus akceleráció & Extracardiális \\
\hline 2. & Nincs & Normál & Pitvarfibrilláció & Alacsony SV vagy vazovagális \\
\hline 3. & Nincs & Normál & PSVT & Alacsony SV vagy vazovagális \\
\hline 4. & Nincs & Normál & Kamrai tachycardia & Alacsony SV vagy vazovagális \\
\hline
\end{tabular}




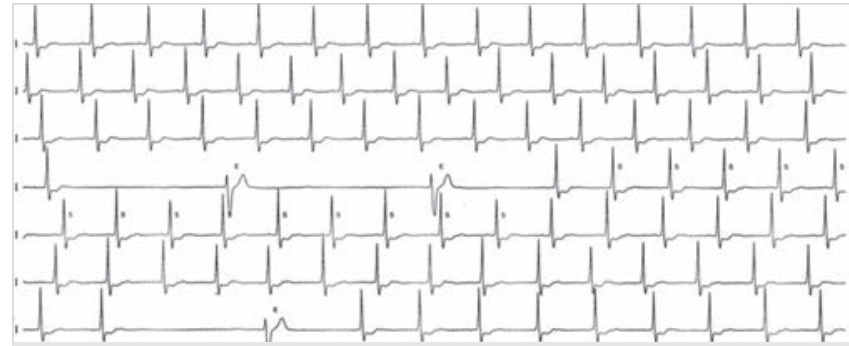

2. ÁBRA. Holter-monitor gyakori presyncope/syncope miatt, aminek hátterében sinus arrestek voltak

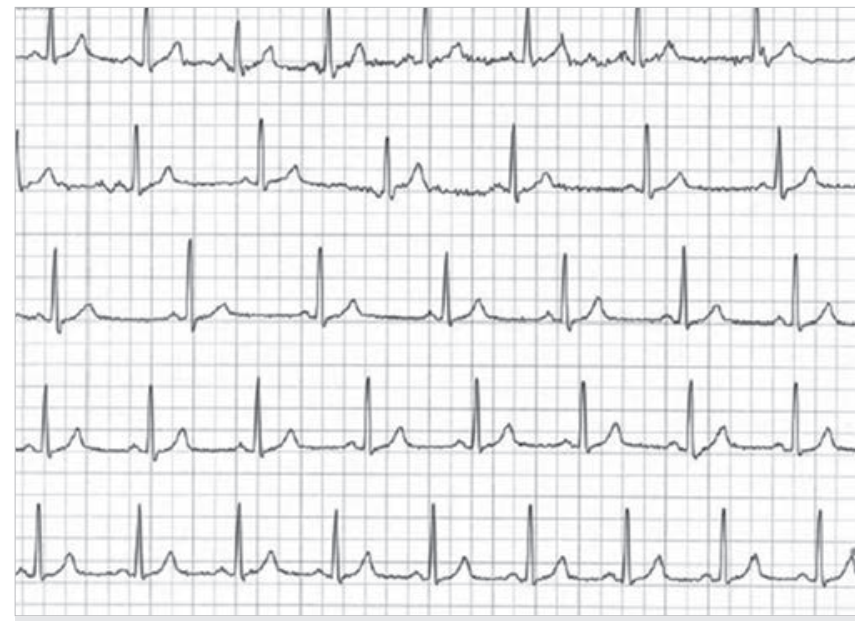

3. ÁBRA. Externális loop rekorderrel felvett presyncopés rosszullét alatt csak enyhe sinus unduláció látszik

Az 1. ábra egy olyan beteg kórházi monitorozásának diagnosztikus szakaszát mutatja ahol a meglévő strukturálás szívbetegség miatt kellett a kórházi kivizsgálás.

A második esetben a strukturális szívbetegség hiánya és a gyakori (naponta 1-2 szer) presyncope, syncope miatt történt a Holter-vizsgálat (2. ábra).

A harmadik esetben szintén strukturális szívbetegség nélküli fiatal lánynál történt externális loop rekorder, mert panaszai csak havi 1-2 alkalommal jelentkeztek (3. ábra).

Végezetül egy enyhe hipertóniás, 60 éves bal Tawaraszár-blokkos férfinak az elmúlt fél évben $2 \times$ jelentkező syncopéja miatt történt implantábilis loop rekorder-beültetés, ami nem sokkal később a paroxizmális III. fokú AV-blokk diagnózisát adta (4. ábra).

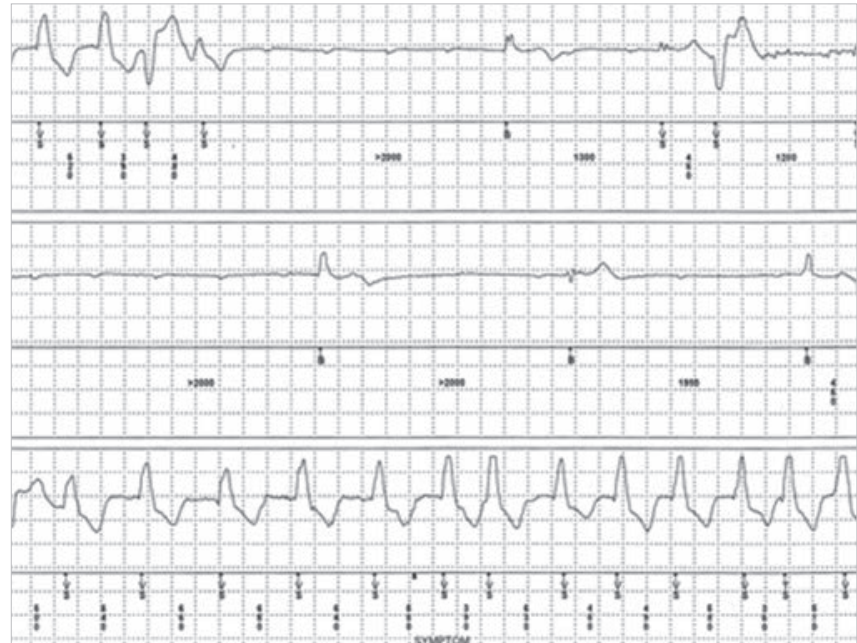

4. ÁBRA. Implantábilis loop rekorder (ILR) recidív syncopék miatt. A betegnél a syncopék miatt koronária CT-t terveztek, ugyanakkor a vezetéstől nem tiltották el. Az ILR paroxizmális III. fokú AV-blokkot igazolt, ami miatt pacemaker-beültetés történt

\section{Következtetések}

Az EKG-monitorozás egy fontos része syncopés beteg kivizsgálásánál, ahol monitorozás fajtájának kiválasztása mind effektivitás, mind gazdasági szempontból egy fontos tényező. Habár az ILR egy nem olcsó beavatkozás, de igen effektív, amivel számos egyéb felesleges vizsgálatot ki lehetne váltani, ha gyakrabban gondolnánk rá és közelítenénk az európai átlaghoz, ami közel négyszerese a hazai beültetéseknek.

Irodalom

1. Shen W-K, Sheldon RS, Benditt DG, et al. 2017 ACC/AHA/HRS Guideline for the evaluation and management of patients with syncope. J Am Coll Cardiol 2017; DOI 10.1016/i.jacc.2017.03.003

2. Edvardson N, et al. Use of an implantable loop recorder to increase the diagnostic yield in unexplained syncope: The results from the PICTURE registry. Europace 2011; 13: 262-9. DOI: 10.1093/europace/euq418

3. Somlói M, Toldy-Schedel E, Nényei Z, et al. Az implantálható loop rekorder szerepe a syncope diagnosztikában: egy hatékony vizsgálatî módszer bevezetésének eredményei. Orv Hetil 2015; 156: 609-613. DOI: $10.1556 / \mathrm{OH} .2015 .30124$

4. Sciaraffin E, Chen J, Hocini M, et al. Use of event recorders and loop recorders in clinical practice: results of the European Heart Rhythm Association Survey. Europace 2014; 16: 1384-1386. DOl: 10.1093/europace/euu222

5. Brignole M, Moya A, Menozzi C, et al. Proposed electrocardiographic classification of spontaneous syncope documented by an implantable loop recorder. Europace 2005; 7(1): 14-18. DOI: 10.1016/j. eupc.2004.11.001 